\title{
Correction to: PML: Regulation and multifaceted function beyond tumor suppression
}

Kuo-Sheng $\mathrm{Hsu}^{1,3}$ and Hung-Ying $\mathrm{KaO}^{1,2^{*}}$ (1)

\section{Correction to: Cell Biosci (2018) 8:5}

https://doi.org/10.1186/s13578-018-0204-8

In the publication of this article [1], there is an error in Table 3 . The position of the black arrow and the terms CBP, Cdk1/2 and STAT3 of Table 3 were placed incorrectly in the online version while these were placed correctly in the PDF.

The error:

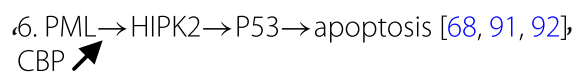

Should instead read:

،6. PML $\rightarrow$ HIPK2 $\rightarrow$ P53 $\rightarrow$ apoptosis [68, 91, 92]

CBP is placed below HIPK2 and points P53.

The error:

،2. Hypoxia $\rightarrow$ Cul3-KLHL20-| PML-| HIF1 $\rightarrow$ angiogenesis [58], $\checkmark \mathrm{Cdk} 1 / 2 \lambda$

Should instead read:

،2. Hypoxia $\rightarrow$ Cul3-KLHL20-| PML-| HIF1 $\rightarrow$ angiogenesis [58], $\lambda \mathrm{Cdk} 1 / 2 \lambda$

Cdk2 is placed below Cul3-KLHL20. Hypoxia points Cdk2 and Cdk2 inhibits PML.

The error:

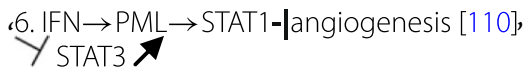

Should instead read:

،6. IFN $\rightarrow$ PML $\rightarrow$ STAT1-langiogenesis [110],

STAT3 is placed below STAT1. PML inhibits STAT3 and STAT3 points angiogenesis.
This has now been updated in the original article [1].

\section{Author details}

${ }^{1}$ Department of Biochemistry, Case Western Reserve University, 10900 Euclid Avenue, Cleveland, OH 44106, USA. ${ }^{2}$ The Comprehensive Cancer Center of Case Western Reserve University and University Hospitals of Cleveland, Cleveland, OH 44106, USA. ${ }^{3}$ Present Address: Tumor Angiogenesis Section, Mouse Cancer Genetics Program (MCGP), National Cancer Institute (NCI), NIH, Frederick, MD 21702, USA.

The original article can be found online at https://doi.org/10.1186/ s13578-018-0204-8.

\section{Publisher's Note}

Springer Nature remains neutral with regard to jurisdictional claims in published maps and institutional affiliations.

Received: 30 January 2018 Accepted: 30 January 2018 Published online: 06 March 2018

\section{Reference}

1. Hsu K-S, Kao H-Y. PML: Regulation and multifaceted function beyond tumor suppression. Cell Biosci. 2018;8:5. https://doi.org/10.1186/ s13578-018-0204-8

*Correspondence: hxk43@cwru.edu

' Department of Biochemistry, Case Western Reserve University, 10900

Euclid Avenue, Cleveland, OH 44106, USA

Full list of author information is available at the end of the article provided you give appropriate credit to the original author(s) and the source, provide a link to the Creative Commons license, and indicate if changes were made. The Creative Commons Public Domain Dedication waiver (http://creativecommons.org/ publicdomain/zero/1.0/) applies to the data made available in this article, unless otherwise stated. 